\title{
Acute and Subacute Studies of Thevetia peruviana Seed Methanol Extracts on Wistar Male Albino Rats
}

\author{
NESY EA*, J. PADIKKALA ${ }^{1}$ AND LIZZY MATHEW ${ }^{2}$ \\ Department of Botany, Kodungallur Kunhikuttan Thampuran Memorial Government College, Pullut, Thrissur, Kerala 680663, \\ ${ }^{1}$ Department of Biochemistry, Amala Cancer Research Institute, Thrissur, Kerala 680555, ${ }^{2}$ Department of Botany, St. Teresa's \\ College, Ernakulam, Kerala 682011, India
}

\section{Ea et al.: Toxicity Studies of Thevetia peruviana Seed Extracts on Wistar Rats}

\begin{abstract}
Thevetia peruviana seed kernels are widely used for suicide attempts in many countries including India. The aim of the present study was to evaluate the level of toxicity exposure of seed kernels by acute and subacute studies on male Wistar albino rats. Haematological parameters and serum biochemical studies were performed in all treated and control groups. In acute toxicity studies, no mortality was observed in groups treated with 100 and $250 \mathrm{mg} / \mathrm{kg}$ animals, but the mortality rate was $100 \%$ in $500 \mathrm{mg} / \mathrm{kg} \mathrm{category}$. Lethality (lethal dose $50 \%$ ) associated with $70 \%$ methanol extract was calculated as $375 \mathrm{mg} / \mathrm{kg}$, revealed the narrow margin of safety lies in between 250 and $500 \mathrm{mg} / \mathrm{kg}$. Exposure to subacute doses did not make any significant changes $(p>0.05)$ in physical parameters like body weight and feeding habits of all treated groups $(25,50$ and $100 \mathrm{mg} / \mathrm{kg}$ for consecutive $14 \mathrm{~d})$. All groups recorded a progressive weight gain and normal food consumption and water intake $(p>0.05)$ as compared with control. Total erythrocytes, haemoglobin concentration, lipid profile, serum electrolytes, bicarbonates, liver functioning enzymes, total protein, albumin, bilirubin, renal urea and creatinine levels were recorded normal in acute and subacute groups. From this experiment it is concluded that the level of toxicity and safety margin is very narrow and the seeds really take lives of organisms, whether the intake is accidental or deliberate.
\end{abstract}

Key words: Thevetia peruviana seed kernels, lethal dose, haemogram profile, renal profile, lipid profile, serum electrolytes

Herbs and herbal preparations have played a vital role in health and disease management for centuries. As medicinal plants contain complex mixtures of many bioactive principles, it is difficult to map out all the unraveled interactions and synergies that may take place between them, the safety of herbal medicines cannot be guaranteed ${ }^{[1]}$. Hence, it will be worth to analyze the side effects of any crude preparation before enlisting as a source of herbal remedy.

Most members of family Apocynaceae are enlisted as medicinal as well as toxic plants because of the narrow margin of safety between therapeutic and toxic doses that the cardiac glycosides encompass. Digoxin, an irreplaceable drug for heart diseases isolated from the fermented foliage of foxglove (Digitalis lanata) is found in a mixture of secondary glycosides, which has not been synthesized yet because of its complex structure ${ }^{[2]}$. Moreover, these plant derived cardiac drugs have no alternatives to conventional medicines ${ }^{[3]}$. The term cardiac glycosides are commonly used to represent a wide variety of steroid derivatives that have the property

*Address for correspondence

E-mail: nesyiby@yahoo.in

September-October 2021 of increasing the force of myocardial contraction and felicitating characteristic electro-physiological effect on the heart ${ }^{[4]}$. The investigating taxon Thevetia peruviana is considered as a therapeutically significant cardioactive plant with toxicological properties like Digitalis.

Despite the toxicity, whole plant and various plant parts like bark, leaves, roots and seeds have been used as cathartic, emetic, diuretic, febrifuge and purgative ${ }^{[5,6]}$ to cure bladder stones, dropsy, edema, intermitted fevers, haemorrhoids, insomnia, tumors, rheumatism and ulcers ${ }^{[7,8]}$, besides its potential role in healing acne, constipation, nausea, cardiac disorders, fever and measles.

This is an open access article distributed under the terms of the Creative Commons Attribution-NonCommercial-ShareAlike 3.0 License, which allows others to remix, tweak, and build upon the work non-commercially, as long as the author is credited and the new creations are licensed under the identical terms

Accepted 03 October 2021

Revised 03 August 2021

Received 26 February 2020

Indian J Pharm Sci 2021;83(5):1000-1006 
For the safe use of medicinal plants, an evaluation of its toxicity is essential. The prime task of toxicological evaluation of any herbal medicine is to identify the nature and significance of adverse effects and to determine the limits of exposure level where the effect is observed ${ }^{[3]}$. This test measures the relative toxicological response of an experimental organism to single or brief exposure to a test substance ${ }^{[9]}$. Subacute oral toxicity studies of herbal medicines are essential to identify the safety and to determine the dose levels that could be useful afterwards ${ }^{[10]}$.

In India and Sri Lanka, deliberate seed intake of 'yellow oleander' with suicidal and homicidal purpose and as an abortifacient was in usual practice ${ }^{[8,11]}$. Also, the exposure of yellow oleander poisoning cases in humans with various clinical complications like vomiting, diarrhea, arrhythmias and palpitation are widely discussed ${ }^{[12-14]}$. Hence, the present work was carried out to explore the toxic exposure levels and related metabolic abnormalities in essential organs at primary level taking Wistar rat as an animal model.

\section{MATERIALS AND METHODS}

\section{Animals:}

Male Wistar albino rats with an average body weight of 45-50 g were procured from the Small Animal Breeding Station (SABS), Kerala Veterinary and Animal Sciences University, Mannuthy, Kerala, India and maintained under standard environmental conditions in the animal house of Amala Cancer Research Centre, Trichur. During the acclimatization period of $4 \mathrm{w}$, rats were fed with ad libitum access to standard pellet diet and tap water in graduated bottles. They were divided into various groups for acute and subacute studies, after attaining 170-190 g body weight. All animal experiments were conducted as per Organization for Economic Co-operation and Development (OECD) guidelines (423) and with prior permission of the Institutional Animal Ethics Committee (IAEC) of the Research Centre, approved by Government of India.

\section{Preparation of drug samples:}

Approximately $60 \mathrm{~g}$ coarsely powdered seed kernels of yellow oleander were de-fatted with petroleum ether and extracted using $70 \%$ Methanol (MT) in a soxhlet extractor for 20-22 h. The residue was collected, evaporated off the solvent and stored in airtight bottles at $4^{\circ}$, for toxicity studies.

\section{Acute toxicity study:}

Twenty male Wistar rats of an average body weight $(182 \mathrm{~g})$ were divided into four groups of five each and were given a single oral dose of the seed extract (Table 1). All animals were fasted for 2-3 h before and after drug administration. They were observed continuously for the first $6 \mathrm{~h}$ for any behavioral and clinical changes, followed by $72 \mathrm{~h}$ monitoring of mortality rates. Body weight, food consumption and water intake were recorded for a period of $14 \mathrm{~d}$. Lethal dose $50 \%\left(\mathrm{LD}_{50}\right)$ was calculated using the arithmetic method of Karbar, modified by Alui and Nwude ${ }^{[15]}$ using the formula $\mathrm{LD}_{50}=\mathrm{LD}_{100}-(\mathrm{Dd} \times \mathrm{Md}) / \mathrm{N}$; where $\mathrm{LD}_{100}=$ Dose that caused $100 \%$ mortality; N=Number of animals per group; $\mathrm{Dd} \times \mathrm{Md}=$ Dose difference $(\mathrm{Dd})$ multiplied by mean death (Md).

\section{Subacute toxicity study:}

After determining $\mathrm{LD}_{50}$ level of the extract, subacute studies were conducted in adult rats, in four groups of five each.

All animals were given oral doses of drugs for consecutive $14 \mathrm{~d}$, with simultaneous observation of clinical changes, weight loss, behavioral changes and feeding habits. On $15^{\text {th }} \mathrm{d}$ animals were sacrificed and blood samples were collected in heparinised and non-heparinised vials for haematological and serum biochemical studies. Vital internal organs such as liver, kidney, heart and brain were dissected out, observed visually for any necrotic lesions, washed in chilled phosphate buffered saline (PBS), blotted dry and weighed. All tissue samples and plasma were stored at $-80^{\circ}$ for further analyses.

Haematological parameters viz. haemoglobin concentration, total erythrocyte, differential leukocyte and platelet counts were analyzed using a Hitachi blood cell counter. Blood samples collected in nonheparinised tubes were allowed to clot, centrifuged at $3000 \mathrm{rpm}$ for $5 \mathrm{~min}$. Separated serum was collected in $1.5 \mathrm{ml}$ Eppendorf tubes and stored in $-20^{\circ}$ to perform

TABLE 1: GROUPS OF ANIMALS FOR ACUTE AND SUBACUTE STUDIES

\begin{tabular}{lcc}
\hline Group & Acute toxicity doses & Subacute toxicity doses \\
\hline I & Control (1 ml vehicle) & Control \\
II & $100 \mathrm{mg} / \mathrm{kg}$ body weight & $25 \mathrm{mg} / \mathrm{kg}$ body weight \\
III & $250 \mathrm{mg} / \mathrm{kg}$ body weight & $50 \mathrm{mg} / \mathrm{kg}$ body weight \\
IV & $500 \mathrm{mg} / \mathrm{kg}$ body weight & $100 \mathrm{mg} / \mathrm{kg}$ body weight \\
\hline
\end{tabular}

Note: Different doses of oral administration to four groups of animals 
biochemical assays like lipid profile, serum electrolytes, Bicarbonates $\left(\mathrm{HCO}_{3}\right)$, liver functioning enzymes such as Serum Glutamic Oxaloacetic Transaminase (SGOT), Serum Glutamic Pyruvic Transaminase (SGPT), Alkaline Phosphatase (ALP), total protein, albumin, bilirubin, renal urea and creatinine levels by standard diagnostic kits with the aid of the Hitachi-902 Automatic Biochemistry Analyzer.

\section{Analysis of data:}

The results are expressed as mean values \pm Standard Deviation (SD). One way Analysis of Variance (ANOVA) with post-hoc Tukey's Honest Significant Difference (HSD) test was used to compare significant differences between group means, using Statistical Package for the Social Sciences (SPSS) software version 20 (2012). A level of $p<0.05$ was regarded as statistically significant.

\section{RESULTS AND DISCUSSION}

Experimental animal models have been successfully utilized to evaluate various treatment protocols intended to manage toxic oleander exposures. In acute toxicity studies, no mortality was observed in Group I (Control), Group II (100 mg/kg) and Group III (250 mg/ $\mathrm{kg}$ ) animals, but the mortality rate was $100 \%$ in Group IV $(500 \mathrm{mg} / \mathrm{kg}$ ) category (Table 2$)$. These animals died within 10-12 h of drug administration with severe, marked clinical manifestations such as abnormal sweating, disorientation, paralysis and rolling of the body. An $\mathrm{LD}_{50}$ of $375 \mathrm{mg} / \mathrm{kg}$ was calculated which indicated a narrow safety margin when compared with the preceding group $(250 \mathrm{mg} / \mathrm{kg})$.

A significant decrease $(\mathrm{p}<0.01)$ in average body weight in $250 \mathrm{mg} / \mathrm{kg}$ treated group and a slow weight gain $(5 \%)$ in $100 \mathrm{mg} / \mathrm{kg}$ group was observed against the normal weight gain $(10 \%)$ in the control group during $2 \mathrm{w}$ of observation. Similarly, $250 \mathrm{mg} / \mathrm{kg}$ treated group showed a decrease in food consumption $(\mathrm{p}<0.01)$ and water intake $(p<0.001)$, but $100 \mathrm{mg} / \mathrm{kg}$ group showed no significant changes $(\mathrm{p}>0.05)$ when compared to the untreated group (Table 3). There was a strong, positive correlation between body weight, food consumption $(\mathrm{p}<0.05)$ and water intake $(\mathrm{p}<0.01)$ in group IV animals.

$\mathrm{LD}_{50}=\mathrm{LD}_{100}-(\mathrm{Dd} \times \mathrm{Md}) / \mathrm{N}$

Where $\mathrm{LD}_{100}=500 ; \mathrm{N}=5 ; \mathrm{Dd} \times \mathrm{Md}=500 \times 1.25$

$$
\begin{aligned}
\mathrm{LD}_{50} & =500-(5001.25) / 5 \\
& =375 \mathrm{mg} / \mathrm{kg} \text { body weight }
\end{aligned}
$$

Exposure to subacute doses did not make any significant changes $(p>0.05)$ in physical parameters like body weight and feeding habits of all treated groups against the control group. All groups recorded a progressive weight gain, normal food consumption and water intake ( $>0.05)$ as compared with control, recorded on every $3^{\text {rd }} \mathrm{d}$ throughout the dosing period.

Normal morphological nature of vital organs indicated that the extract did not affect their metabolism adversely (Table 4). Statistically analyzed data between control versus all three treated groups showed no significant variation in liver $(4.03 \pm 0.21$ to $4.10 \pm 0.05 \mathrm{~g})$, kidney $(0.74 \pm 0.04$ to $0.73 \pm 0.06)$ and heart $(0.31 \pm 0.02$ to $0.27 \pm 0.02)$, weight $(\mathrm{p}>0.05)$, but there was a significant decrease in brain weight $(\mathrm{p}<0.01)$ of group IV animals $(0.68 \pm 0.06)$ compared to control group $(0.80 \pm 0.02)$. However, no significant variations were observed in Hemoglobin $(\mathrm{Hb})$ content $(14.25 \pm 0.78$ to 15.33 $\pm 1.07 \mathrm{mg} \%$ ), Red Blood Cells (RBC) (7.65 \pm 0.21 to $6.54 \pm 0.2310^{3} / \mathrm{mm}^{3}$ ), total and differential White Blood Cells (WBC) counts $(8850.00 \pm 954.50$ to $7766.67 \pm 1942.51$ cells $/ \mathrm{mm}^{3}$ ) and platelet counts $\left(7.75 \pm 0.35\right.$ to $\left.8.37 \pm 0.7810^{5} / \mathrm{mm}^{3}\right)$ in all three treated groups ( $\mathrm{p}>0.05$ ) compared to control group (Table 5).

Proper functioning of the liver was assayed by various enzyme markers such as SGOT, SGPT and ALP that were present in the serum (Table 6). Results showed an insignificant increase in the serum SGOT level of group IV animals (110.67 $\pm 9.02 \mathrm{U} / \mathrm{l})$, however, the values were within the normal reference levels. No significant changes were observed in SGPT

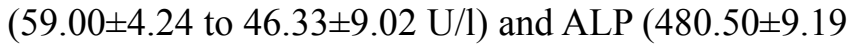

TABLE 2: ACUTE TOXICITY (LD $\left.{ }_{50}\right)$ STUDIES IN WISTAR RATS SHOWING SURVIVAL/MORTALITY RATES

\begin{tabular}{lccccc}
\hline Groups & Dose (mg/kg body weight) & Dd & No. of animals/group (N) & Mortality (Death/Survival) & Md \\
\hline Group I & (Control) & 0 & 5 & 0 & 0 \\
Group II & 100 & 100 & 5 & 0 & 0 \\
Group III & 250 & 150 & 5 & 0 & 0 \\
Group IV & 500 & 250 & 5 & $5 / 5$ & 5 \\
& & 500 & & & 1.25
\end{tabular}

Note: Different doses and dose differences in four groups of animals 
TABLE 3: EFFECT OF SEED EXTRACT ON BODY WEIGHT AND FEEDING HABITS IN WISTAR RATS DURING SUBACUTE STUDIES

\begin{tabular}{lcccccc}
\hline Treatments & $\mathrm{d} \mathrm{0}$ & $\mathrm{d} \mathrm{3}$ & $\mathrm{d} 6$ & $\mathrm{~d} \mathrm{9}$ & $\mathrm{d} 12$ & $\mathrm{~d} 15$ \\
\hline Body weight $(\mathrm{g})$ & & & & & & \\
Control & $150.67 \pm 15.14$ & $161.00 \pm 13.42$ & $182.00 \pm 10.43$ & $191.22 \pm 8.97$ & $198.11 \pm 3.66$ & $200.17 \pm 4.49$ \\
$25 \mathrm{mg} / \mathrm{kg}$ & $159.80 \pm 3.56$ & $172.00 \pm 6.01$ & $184.20 \pm 11.22$ & $200.13 \pm 10.61$ & $205.07 \pm 12.52$ & $217.40 \pm 14.12$ \\
$50 \mathrm{mg} / \mathrm{kg}$ & $158.40 \pm 6.31$ & $173.60 \pm 14.14$ & $190.20 \pm 10.74$ & $207.73 \pm 7.64$ & $220.73 \pm 5.69$ & $230.70 \pm 4.42$ \\
$100 \mathrm{mg} / \mathrm{kg}$ & $187.40 \pm 9.32$ & $194.47 \pm 10.56$ & $207.00 \pm 11.27$ & $223.47 \pm 9.39$ & $234.93 \pm 13.43$ & $241.40 \pm 16.30$ \\
Food intake $(\mathrm{g})$ & & & & & & \\
Control & $105.83 \pm 8.25$ & $108.33 \pm 11.67$ & $108.89 \pm 14.17$ & $90.00 \pm 10.93$ & $83.33 \pm 8.33$ & $121.67 \pm 2.36$ \\
$25 \mathrm{mg} / \mathrm{kg}$ & $101.00 \pm 1.41$ & $107.33 \pm 32.35$ & $112.33 \pm 32.33$ & $105.67 \pm 8.14$ & $98.33 \pm 5.77$ & $135.50 \pm 17.68$ \\
$50 \mathrm{mg} / \mathrm{kg}$ & $74.00 \pm 5.66$ & $84.00 \pm 38.51$ & $113.33 \pm 10.54$ & $112.67 \pm 3.21$ & $109.00 \pm 4.58$ & $123.50 \pm 27.58$ \\
$100 \mathrm{mg} / \mathrm{kg}$ & $108.00 \pm 11.31$ & $125.67 \pm 3.79$ & $123.67 \pm 4.73$ & $113.00 \pm 10.44$ & $102.67 \pm 6.81$ & $119.00 \pm 21.21$ \\
Water intake (ml) & & & & & & \\
Control & $91.67 \pm 0.00$ & $115.56 \pm 20.84$ & $97.2 \pm 29.62$ & $94.44 \pm 12.73$ & $86.11 \pm 4.81$ & $100.00 \pm 23.57$ \\
$25 \mathrm{mg} / \mathrm{kg}$ & $85.00 \pm 0.00$ & $83.33 \pm 22.55$ & $111.67 \pm 33.29$ & $101.67 \pm 2.89$ & $131.67 \pm 18.93$ & $100.00 \pm 0.00$ \\
$50 \mathrm{mg} / \mathrm{kg}$ & $30.00 \pm 0.00$ & $56.67 \pm 40.41$ & $113.33 \pm 35.12$ & $118.33 \pm 11.55$ & $106.67 \pm 40.41$ & $95.00 \pm 35.36$ \\
$100 \mathrm{mg} / \mathrm{kg}$ & $105.00 \pm 21.21$ & $85.00 \pm 13.23$ & $103.33 \pm 22.55$ & $113.33 \pm 18.03$ & $106.67 \pm 30.55$ & $102.50 \pm 10.61$ \\
\hline
\end{tabular}

Note: Body weight, food consumption and water intake of experimental animals from d 1 to 15 . Values are mean $\pm S D$; all values are $p>0.05$

TABLE 4: RELATIVE ORGAN WEIGHT OF CONTROL AND TREATED GROUPS

\begin{tabular}{lcccc}
\hline Treatments & Liver & Kidney & Heart & Brain \\
\hline Control & $4.03 \pm 0.21$ & $0.74 \pm 0.04$ & $0.31 \pm 0.02$ & $0.80 \pm 0.02$ \\
$25 \mathrm{mg} / \mathrm{kg}$ & $4.06 \pm 0.21$ & $0.70 \pm 0.00$ & $0.31 \pm 0.02$ & $0.73 \pm 0.02$ \\
$50 \mathrm{mg} / \mathrm{kg}$ & $3.84 \pm 0.08$ & $0.69 \pm 0.08$ & $0.31 \pm 0.00$ & $0.74 \pm 0.03$ \\
$100 \mathrm{mg} / \mathrm{kg}$ & $4.10 \pm 0.05$ & $0.73 \pm 0.06$ & $0.27 \pm 0.02$ & $0.68 \pm 0.06^{*}$ \\
\hline
\end{tabular}

Note: Weight of liver, kidney, heart and brain in grams. Values are mean \pm SD, all values are $p>0.05,{ }^{*} p<0.01$

TABLE 5: EFFECT OF SEED EXTRACT ON HAEMOGRAM PROFILE

\begin{tabular}{|c|c|c|c|c|}
\hline Parameters & $\begin{array}{c}\text { Group I } \\
\text { (Control) }\end{array}$ & $\begin{array}{c}\text { Group II } \\
(25 \mathrm{mg} / \mathrm{kg})\end{array}$ & $\begin{array}{c}\text { Group III } \\
(50 \mathrm{mg} / \mathrm{kg})\end{array}$ & $\begin{array}{c}\text { Group IV } \\
(100 \mathrm{mg} / \mathrm{kg})\end{array}$ \\
\hline $\mathrm{Hb}(\mathrm{g} \%)$ & $14.25 \pm 0.78$ & $14.85 \pm 0.64$ & $15.10 \pm 1.15$ & $15.33 \pm 1.07$ \\
\hline $\mathrm{RBC}\left(10^{3} / \mathrm{mm}^{3}\right)$ & $7.65 \pm 0.21$ & $7.39 \pm 0.29$ & $7.44 \pm 0.37$ & $6.54 \pm 0.23$ \\
\hline Mean corpuscular volume (MCV) (fl) & $61.90 \pm 1.27$ & $60.65 \pm 0.21$ & $59.73 \pm 1.19$ & $60.73 \pm 0.75$ \\
\hline Mean corpuscular hemoglobin $(\mathrm{MCH})(\mathrm{pg})$ & $19.05 \pm 1.06$ & $20.05 \pm 0.07$ & $20.23 \pm 0.51$ & $20.63 \pm 0.84$ \\
\hline Mean corpuscular hemoglobin concentration $(\mathrm{MCHC})(\mathrm{g} / \mathrm{dl})$ & $30.55 \pm 2.05$ & $33.15 \pm 0.21$ & $33.93 \pm 0.40$ & $34.07 \pm 0.91$ \\
\hline Hematocrit (HCT)-packed cell volume (PCV) (\%) & $46.05 \pm 1.48$ & $45.00 \pm 1.41$ & $44.67 \pm 3.06$ & $45.00 \pm 2.00$ \\
\hline Platelets $\left(10^{5} / \mathrm{mm}^{3}\right)$ & $7.75 \pm 0.35$ & $7.28 \pm 0.02$ & $7.47 \pm 0.70$ & $8.37 \pm 0.78$ \\
\hline WBC (cells $/ \mathrm{mm}^{3}$ ) & $8850 \pm 954$ & $8750 \pm 606$ & $9333 \pm 312$ & $7766 \pm 425$ \\
\hline Neutrophils (\%) & $27.50 \pm 3.54$ & $23.50 \pm 0.71$ & $17.33 \pm 3.06$ & $17.67 \pm 7.23$ \\
\hline Lymphocytes (\%) & $70.50 \pm 2.12$ & $69.00 \pm 1.41$ & $75.67 \pm 2.89$ & $73.67 \pm 6.51$ \\
\hline Eosinophils (\%) & $2.00 \pm 0.00$ & $7.5 \pm 0.71$ & $7.00 \pm 1.00$ & $8.67 \pm 2.89$ \\
\hline
\end{tabular}

Note: Haemoglobin, platelets and differential counts in the blood of animals under subacute study, Values are mean \pm SD; all values are $\mathrm{p}>0.05$

to $434.67 \pm 49.17 \mathrm{U} / 1)$ levels of treated groups ( $>0.05$ ) when compared with group I (control). Similarly, there was no change in total protein $(7.30 \pm 0.14$ to $7.60 \pm 0.52 \mathrm{~g} / \mathrm{dl})$ and bilirubin levels $(0.50 \pm 0.00$ to $0.43 \pm 0.15 \mathrm{mg} / \mathrm{dl})$ in the treated groups ( $>0.05)$ and an undisturbed albumin globulin ratio was observed in all treated groups.
Renal functioning was assayed by estimating the level of creatinine and urea in blood serum (Table 7). There were no statistically significant differences in urea level of treated animal groups $(31.50 \pm 2.12$ to 33.00 $\pm 6.56 \mathrm{mg} / \mathrm{dl})$, but the slight decrease observed in creatinine level of group II and III $(0.49 \pm 0.06$ and $0.48 \pm 0.06 \mathrm{mg} / \mathrm{dl})$ when compared with control 
$(0.65 \pm 0.07)$ were found as statistically insignificant $(\mathrm{p}>0.05)$.

There was no statistically significant difference between the groups of all treated groups against the control animals in total cholesterol level, triglycerides, High-Density Lipoprotein (HDL), Very Low-Density Lipoprotein (VLDL) and low-density lipoprotein (LDL) $(p>0.05)$. The level of serum electrolytes (sodium $(\mathrm{Na})$, potassium $(\mathrm{K})$, chloride and bicarbonates) was found unaltered (Table 8 ) in the treated groups significantly $(\mathrm{p}>0.05)$. The normal level of these electrolytes was represented as $143.70 \pm 1.84,7.40 \pm 0.28$ and 24.50 $\pm 0.71 \mathrm{mmol} / \mathrm{l}$ and higher dosage animals $(100 \mathrm{mg} / \mathrm{kg})$ recorded $140.83 \pm 3.41, \quad 5.22 \pm 0.78$ and 23.00 $\pm 1.00 \mathrm{mmol} / 1$ respectively (Table 9 ). The chloride level in serum was also found to be unaltered and represented by $98.70 \pm 0.99$ (control group) to $93.55 \pm 1.34$, $93.71 \pm 1.18$ and $93.03 \pm 1.04$ in all three treated groups correspondingly.

Toxicity is the relative ability of a substance to cause injury to biologic tissues ${ }^{[16]}$. Studies were conducted to determine the safety and efficacy levels, the lethal dose and related metabolic alterations and pharmacological manifestations using acute and subacute guidelines of the OECD.

TABLE 6: EFFECT OF SEED EXTRACT ON LIVER FUNCTIONING ENZYMES IN SERUM

\begin{tabular}{lcccc}
\hline Parameters & Group I (Control) & $\begin{array}{c}\text { Group II } \\
(25 \mathrm{mg} / \mathrm{kg})\end{array}$ & $\begin{array}{c}\text { Group III } \\
\mathbf{5 0} \mathbf{~ m g} / \mathbf{k g})\end{array}$ & $\begin{array}{c}\text { Group IV } \\
(\mathbf{1 0 0} \mathrm{mg} / \mathrm{kg})\end{array}$ \\
\hline SGOT $(\mathrm{U} / \mathrm{l})$ & $69.00 \pm 9.90$ & $98.00 \pm 35.36$ & $85.00 \pm 12.12$ & $110.67 \pm 9.02$ \\
SGPT $(\mathrm{U} / \mathrm{l})$ & $59.00 \pm 4.24$ & $46.50 \pm 19.09$ & $45.67 \pm 5.13$ & $46.33 \pm 9.02$ \\
ALP $(\mathrm{U} / \mathrm{l})$ & $480.50 \pm 9.19$ & $428.00 \pm 45.96$ & $403.00 \pm 87.02$ & $434.67 \pm 49.17$ \\
Total protein $(\mathrm{g} / \mathrm{dl})$ & $7.30 \pm 0.14$ & $7.40 \pm 0.00$ & $7.57 \pm 0.40$ & $7.60 \pm 0.52$ \\
Albumin $(\mathrm{g} / \mathrm{dl})$ & $4.25 \pm 0.07$ & $4.45 \pm 0.07$ & $4.70 \pm 0.36$ & $4.63 \pm 0.49$ \\
Globulin $(\mathrm{g} / \mathrm{dl})$ & $3.30 \pm 0.42$ & $2.95 \pm 0.07$ & $2.87 \pm 0.06$ & $2.97 \pm 0.06$ \\
Bilirubin, total $(\mathrm{mg} / \mathrm{dl})$ & $0.50 \pm 0.00$ & $0.45 \pm 0.07$ & $0.43 \pm 0.16$ & $0.43 \pm 0.15$ \\
Bilirubin direct $(\mathrm{mg} / \mathrm{dl})$ & $0.2 \pm 0.00$ & $0.15 \pm 0.07$ & $0.13 \pm 0.06$ & $0.13 \pm 0.06$ \\
Bilirubin indirect $(\mathrm{mg} / \mathrm{dl})$ & $0.3 \pm 0.00$ & $0.30 \pm 0.00$ & $0.30 \pm 0.00$ & $0.30 \pm 0.00$ \\
\hline
\end{tabular}

Note: SGOT, SGPT, ALP, total protein and bilirubin analysis during subacute studies. Values are mean \pm SD; all values are $p>0.05$

TABLE 7: EFFECT OF SEED EXTRACT ON RENAL PROFILE

\begin{tabular}{lcccc}
\hline Parameters & Group I (Control) & $\begin{array}{c}\text { Group II } \\
(\mathbf{2 5} \mathbf{~ m g} / \mathbf{k g})\end{array}$ & $\begin{array}{c}\text { Group III } \\
\mathbf{( 5 0} \mathbf{~ m g} / \mathbf{k g})\end{array}$ & $\begin{array}{c}\text { Group IV } \\
(\mathbf{1 0 0} \mathbf{~ m g} / \mathbf{k g})\end{array}$ \\
\hline Creatinine $(\mathrm{mg} / \mathrm{dl})$ & $0.65 \pm 0.07$ & $0.55 \pm 0.07$ & $0.49 \pm 0.06$ & $0.48 \pm 0.06$ \\
Urea $(\mathrm{mg} / \mathrm{dl})$ & $31.50 \pm 2.12$ & $32.00 \pm 9.90$ & $30.67 \pm 3.21$ & $33.00 \pm 6.56$ \\
\hline
\end{tabular}

Note: Creatinine and urea levels in the serum of animals during subacute studies. Values are mean \pm SD; all values are $p>0.05$

TABLE 8: EFFECT OF SEED EXTRACT ON LIPID PROFILE

\begin{tabular}{lcccc}
\hline Parameters & Group I (Control) & $\begin{array}{c}\text { Group II } \\
(\mathbf{2 5} \mathbf{~ m g} / \mathbf{k g})\end{array}$ & $\begin{array}{c}\text { Group III } \\
(\mathbf{5 0} \mathbf{~ m g} / \mathbf{k g})\end{array}$ & $\begin{array}{c}\text { Group IV } \\
(\mathbf{1 0 0} \mathbf{~ m g} / \mathbf{k g})\end{array}$ \\
\hline Total cholesterol $(\mathrm{mg} / \mathrm{dl})$ & $87.00 \pm 7.07$ & $85.5 \pm 6.36$ & $88.33 \pm 9.87$ & $92.33 \pm 14.01$ \\
Triglycerides $(\mathrm{mg} / \mathrm{dl})$ & $61.00 \pm 4.24$ & $72.00 \pm 11.31$ & $75.67 \pm 5.69$ & $78.67 \pm 10.97$ \\
HDL $(\mathrm{mg} / \mathrm{dl})$ & $24.50 \pm 3.54$ & $23.50 \pm 0.71$ & $22.67 \pm 0.58$ & $24.00 \pm 1.00$ \\
LDL $(\mathrm{mg} / \mathrm{dl})$ & $45.50 \pm 3.54$ & $47.50 \pm 3.54$ & $50.67 \pm 9.45$ & $52.67 \pm 12.50$ \\
VLDL $(\mathrm{mg} / \mathrm{dl})$ & $13.00 \pm 1.41$ & $14.50 \pm 2.12$ & $15.00 \pm 1.00$ & $15.67 \pm 2.31$ \\
\hline
\end{tabular}

Note: Level of total cholesterol and triglycerides in the serum of rats during subacute studies. Values are mean \pm SD; all values are $p>0.05$

TABLE 9: EFFECT OF SEED EXTRACT ON SERUM ELECTROLYTES

\begin{tabular}{lcccc}
\hline Parameters & Group I (Control) & $\begin{array}{c}\text { Group II } \\
(\mathbf{2 5} \mathbf{~ m g} / \mathbf{k g})\end{array}$ & $\begin{array}{c}\text { Group III } \\
\mathbf{( 5 0 ~} \mathbf{~ m g} / \mathbf{k g})\end{array}$ & $\begin{array}{c}\text { Group IV } \\
(\mathbf{1 0 0} \mathbf{~ m g} / \mathbf{k g})\end{array}$ \\
\hline $\mathrm{Na}(\mathrm{mmol} / \mathrm{l})$ & $143.70 \pm 1.84$ & $137.80 \pm 1.84$ & $140.10 \pm 2.14$ & $140.83 \pm 3.41$ \\
$\mathrm{~K}(\mathrm{mmol} / \mathrm{l})$ & $7.40 \pm 0.28$ & $5.51 \pm 1.36$ & $6.02 \pm 0.86$ & $5.22 \pm 0.78$ \\
$\mathrm{Cl}(\mathrm{mmol} / \mathrm{l})$ & $96.70 \pm 3.81$ & $93.55 \pm 1.34$ & $93.71 \pm 1.18$ & $93.03 \pm 1.04$ \\
$\begin{array}{l}\text { Bicarbonate }\left(\mathrm{HCO}_{3}\right) \\
\text { (mmol/l) }\end{array}$ & $24.50 \pm 0.71$ & $24.50 \pm 0.71$ & $22.67 \pm 0.58$ & $23.00 \pm 1.00$
\end{tabular}

Note: Level of sodium, potassium, chloride and bicarbonates in the serum. Values are mean \pm SD; all values are $p>0.05$ 
Animals treated with a single dose of extract $(500 \mathrm{mg} / \mathrm{kg}$ ) caused $100 \%$ mortality than the preceding group $(250 \mathrm{mg} / \mathrm{kg})$ which showed no mortality rates, but experienced a reduction in body weight, food consumption and water intake. However, lower dosed animals $(100 \mathrm{mg} / \mathrm{kg})$ showed normal behavior, similar to the control group. Lethality $\left(\mathrm{LD}_{50}\right)$ associated with $70 \%$ MT extract was calculated as $375 \mathrm{mg} / \mathrm{kg}$, revealed the narrow margin of safety lies in between 250 and $500 \mathrm{mg} / \mathrm{kg}$, on seed intake either in raw form or in processed form.

The toxic nature of seeds was further revealed by various researchers. Enriquez et al. ${ }^{[17]}$ observed a lethal dose $\left(\mathrm{LD}_{50}\right)$ of $447 \mathrm{mg} / \mathrm{kg}$ in mice after milled seed administration and Taiwo et al. ${ }^{[18]}$ reported $100 \%$ mortality in rabbits within $14 \mathrm{~d}$, after $10 \%$ raw seed administration. Moreover, a lower lethal dose of $507 \mathrm{mg} / \mathrm{kg}$ with a concentrated aqueous kernel extract and higher dose of $5700 \mathrm{mg} / \mathrm{kg}$ with the bait formulated using $40 \%$ of the kernel meal was observed in albino rats $^{[19]}$, with severe clinical malfunctioning ${ }^{[20]}$. But, the human mortality associated with oleander ingestion is generally very low, even in cases of intentional consumption (suicide attempts) ${ }^{[21]}$ and surprisingly in Mexico, the seeds are widely used to reduce body weight $^{[17]}$.

After determining the lethal level via acute dosage, subacute experiments were carried out for $14 \mathrm{~d}$ of regular oral drug exposure. Since $500 \mathrm{mg} / \mathrm{kg}$ produced severe toxicity symptoms with $100 \%$ lethality $\left(\mathrm{LD}_{100}\right)$, for subacute studies a dose level of $1 / 20^{\text {th }}, 1 / 10^{\text {th }}$ and $1 / 5^{\text {th }}(25,50$ and $100 \mathrm{mg} / \mathrm{kg})$ was selected. The selected doses neither affected body weight nor food consumption and water intake. Adverse reactions often resulted from excess dosage effects of any 'active principles $^{[1]}$.

Normal values of haematological parameters (RBC, WBC and platelets), lipid profiling (cholesterol, triglycerides) and serum electrolytes $(\mathrm{Na}, \mathrm{K})$ are related to the proper metabolism of the endocrine system. Treatment of rats with different doses of the seed kernel extract did not alter the serum marker enzymes in liver (SGOT, SGPT, ALP) and kidney (creatinine, urea), indicated the absence of hepatocellular and nephrocellular necrosis, as elevated levels of blood serum enzymes are indicative of cellular leakage, necrosis and loss of functional integrity of cell membranes $^{[22]}$. The normal morphological behavior of vital organs was concurrent with liver and kidney function tests, which showed normal values in all groups under study, including the highest dose $(100 \mathrm{mg} / \mathrm{kg})$ of administration. However, leaf extract of Nerium oleander, a close relative of yellow oleander, showed significant adverse changes in haematological, biochemical and inflammatory parameters, as well as histopathological alterations in heart and liver tissues ${ }^{[23]}$.

Albumin is one of the key components of serum protein. As albumin is synthesized in the liver, it can be used as a biomarker to monitor liver functions. Serum bilirubin and total protein levels are also related to the functions of hepatic cells. In the present study normal albumin, globulin and bilirubin levels are considered as nondisturbances in protein synthesis in the liver, confirmed the proper functioning of this organ.

In the acute toxicity experiment, a single dose of $500 \mathrm{mg} / \mathrm{kg}$ produced $100 \%$ lethality, but the absence of any clinical manifestations after a cumulative dose of $1400 \mathrm{mg} / \mathrm{kg}$ administered for 14 consecutive days, reflect the detoxification/purification processes carried out by the liver and kidney. The liver is expected not only to perform physiological functions, but also to protect against the hazards of harmful drugs and chemicals $^{[24]}$ by detoxifying most of the components that enter the body ${ }^{[25]}$, while the kidney is a principal route of excretion of many chemical substances in their active and/or inactive forms ${ }^{[26]}$. It is generally accepted that the paramount organ for degradation of cardiotonic steroids is the liver. A significant hepatoprotective activity as well as considerable antioxidant properties was reported by Singhal and Gupta, ${ }^{[27]}$ in flower extracts of Nerium oleander, a close relative of 'yellow oleander' ${ }^{[28]}$.

With the words of Paracelsus (1493-1541) "All substances are poisons; there is none which is not a poison. The right dose differentiates a poison and a remedy", the following conclusions were drawn after toxicity studies of 'yellow oleander' seed kernel extracts. Acute studies revealed that $70 \%$ MT seed extract showed $\mathrm{LD}_{50}$ at $375 \mathrm{mg} / \mathrm{kg}$ body weight and a single oral dose of $500 \mathrm{mg} / \mathrm{kg}$ showed $100 \%$ lethality revealed a narrow margin of safety. Similarly, a single sub-lethal dose $(250 \mathrm{mg} / \mathrm{kg})$ reduced body weight and affected feeding habits. But, a repeated dosage of $100 \mathrm{mg} / \mathrm{kg}$ for consecutive $14 \mathrm{~d}$ did not affect the normal physiology, metabolism and biochemistry of experimental Wistar rats.

\section{Acknowledgements:}

The first author is thankful to University Grants Commission for supporting to complete Ph. D work 
and Amala Cancer Research Institute for carrying out animal studies.

\section{Conflicts of interest:}

The authors declared no conflict of interest.

\section{REFERENCES}

1. George P. Concerns regarding the safety and toxicity of medicinal plants-An overview. J App Pharm Sci 2011;1(6):404.

2. Novkovic VV, Stanojevic LP, Cakic MD, Veljkovic VB, Stankovic MZ. Separation of digoxin by liquid-liquid extraction from extracts of foxglove secondary glycosides. Hem Ind 2014;68(2):161-70.

3. Ifeoma O, Oluwakanyinsola S. Screening of herbal medicines for potential toxicities. New insights into toxicity and drug testing. IntechOpen book series; 2013. p. 63-88.

4. Akera T. Brody TM. Pharmacology of cardiac glycosides. In: Nicholas Sperelakis editor. Physiology and pathophysiology of the heart. 2nd ed. Springer; 1989. p. 453-69.

5. Trivedi PC. Ethno-medico-botany of some sacred plants of Dhemaji district of Assam. In: Medicinal Plants: Traditional knowledge. IK International: New Delhi; 2006. p. 114.

6. Vardhana R. Direct uses of medicinal plants and their identification. Sarup and Sons, Darya Gang, New Delhi; 2008.

7. Joshi SG. Medicinal Plants. Oxford and IBH Publishing Company Pvt. Ltd, New Delhi; 2000.

8. Pullaiah T. Encyclopedia of World medicinal plants. Volume IV. Regency Publications, West Patel Nagar, New Delhi; 2006.

9. OECD. Acute oral toxicity-Acute toxic class method, test guideline No. 423. OECD Guidelines for the Testing of Chemicals, OECD; 2001.

10. Kasthuri OR, Ramesh B. Toxicity studies on leaf extracts of Alternanthera brasiliana (L.) Kuntze and Alternanthera bettzickiana (Regel) Voss. J App Pharm Sci 2018;8(10):82-9.

11. Valkenburg V, Bunyapraphatsara N. Plant resources of South East Asia. No. 12 (2): Medicinal and poisonous plants 2. Backhuys publisher, Leiden: Netherlands; 2001.

12. Saravanapavananthan N, Ganeshamoorthy J. Yellow oleander poisoning-a study of 170 cases. Forensic Sci Int 1988;36(34):247-50.

13. Bose TK, Basu RK, Biswas B, De JN, Majumdar BC, Datta S. Cardiovascular effects of yellow oleander ingestion. J Indian Med Assoc 1999;97(10):407-10.
14. Rajapakse S. Management of yellow oleander poisoning. Clin Toxicol 2009;47(3):206-12.

15. Alui YO, Nwude N. Determination of the median lethal dose $\left(\mathrm{LD}_{50}\right)$. In: Veterinary Pharmacology \& Toxicology Experiments. Baraka Press: Zaria; 1982. p. 104-22.

16. UNL. Environmental Health and Safety. University of Nebraska Lincoln; 2002.

17. Enriquez ME, Ruiz LA, Rosas ML, Guerrero GA, Contreras AA, Sepulveda AE. Acute toxicity of Thevetia peruviana in Rodents. Proc West Pharmacol Soc 2002;45:131-3.

18. Taiwo VO, Afolabi OO, Adegbuyi OA. Effect of Thevetia peruviana seed cake-based meal on the growth, haematology and tissues of rabbits. Trop Subtrop Agroecosyst 2004;4(1):714.

19. Oji O, Okafor QE. Toxicological studies on stem bark, leaf and seed kernel of yellow oleander (Thevetia peruviana). Phytother Res 2000;14(2):133-5.

20. Pahwa R, Chatterjee VC. The toxicity of yellow oleander (Thevetia neriifolia Juss) seed kernels to rats. Vet Hum Toxicol 1990;32(6):561-4.

21. Langford SD, Boor PJ. Oleander toxicity: an examination of human and animal toxic exposures. Toxicology 1996;109(1):13.

22. Drotman RB, Lawhorn GT. Serum enzymes as indicators of chemically induced liver damage. Drug Chem Toxicol 1978;1(2):163-71.

23. Abdou RH, Basha WA, Khalil WF. Subacute toxicity of Nerium oleander ethanolic extract in mice. Toxicol Res 2019;35(3):233-9.

24. Palanivel MG, Rajkapoor B, Kumar RS, Einstein JW, Kumar EP, Kumar MR, et al. Hepatoprotective and antioxidant effect of Pisonia aculeata $\mathrm{L}$. against $\mathrm{CCl}_{4}$-induced hepatic damage in rats. Sci Pharm 2008;76(2):203-16.

25. Nunez M. Hepatotoxicity of antiretrovirals: incidence, mechanisms and management. J Hepatol 2006;44:S132-9.

26. Abdulrahman FI, Onyeyili PA, Sanni S, Ogugbuaja VO. Toxic effect of aqueous root-bark extract of Vitex doniana on liver and kidney functions. Int J Biol Chem Sci 2007;1(4):184-95.

27. Singhal KG, Gupta GD. Hepatoprotective and antioxidant activity of methanolic extract of flowers of Nerium oleander against $\mathrm{CCl}_{4}$-induced liver injury in rats. Asian Pac J Trop Med 2012;5(9):677-85.

28. Nesy EA, Padikkla J, Mathew L. Antioxidant and cardiac enzyme marker studies of Thevetia peruviana seed hydromethanol extract in Wistar male albino rats. Int J Pharm Sci Drug Res 2020;12(4):1-6. 